\title{
LAIKYSENOS KOREKCIJOS EFEKTYVUMAS, TAIKANT SCHROTH KINEZITERAPIJOS METODIKA PAAUGLIŲ IDIOPATINĖS SKOLIOZĖS ATVEJAIS
}

\author{
Romualdas Sinkevičius ${ }^{1,2}$, Eglė Sutkutė ${ }^{1}$, Jonas Kairys ${ }^{1,2}$, Veslava Radzevič ${ }^{1,2}$, \\ Juozas Raistenskis ${ }^{\mathbf{1}, 2}$ \\ ${ }^{1}$ Vilniaus universiteto Medicinos fakulteto Sveikatos mokslu institutas, \\ ${ }^{2}$ Vaiku ligonine, Vilniaus universiteto ligoninès Santaros kliniku filialas
}

Raktažodžiai: idiopatinè skoliozè, Schroth metodas.

\section{Santrauka}

Tyrimo tikslas - ivvertinti Schroth metodikos efektyvumą pacientų raumenų ištvermès, judesių amplitudžių didinimui bei laikysenos korekcijai paauglių idiopatinès skoliozès atvejais.

Tyrimo metodai. Tyrimas vyko nuo $2019 \mathrm{~m}$. vasario iki balandžio mėnesio. Tyrimo vieta - Vaikų ligoninè, Vilniaus univesiteto ligoninès Santaros klinikų (toliau - VULSK) filialas. Tyrime iš viso dalyvavo 20 tiriamujų. Tiriamiesiems buvo taikoma 10 kineziterapijos procedūrų Schroth gydymo metodu. Siekiant ivvertinti tiriamujų sveikatos būklès pokyčius bei kineziterapijos efektyvumą, testavimas buvo atliktas 3 kartus: prieš reabilitaciją, po vienos procedūros ir po reabilitacijos. Laikysenos parametru ivertinimui naudota DIERS Formetric 4D sistema. Liemens raumenu statinès ištvermès vertinimui naudotas McGill testas. Stuburo paslankumas matuotas centimetrine juostele. Taikytos TRACE (laikysenos vertinimo) ir TAPS (savęs suvokimo) skalès. Duomenų analizè atlikta naudojant statistinès analizès programas $\mathrm{R}$ ir Microsoft Excel.

Rezultatai. Taikant Schroth metodiką, po 10 procedūrų reikšmingai pagerejo pilvo, nugaros, kairiojo ir dešiniojo šonų raumenų statinè ištvermè bei stuburo paslankumas ị visas puses. Po 10 Schroth procedūru reikšmingai pagerèjo liemens disbalanso, dubens pakrypimo, paviršiaus rotacijos, lateralinès deviacijos rezultatai. Po 10 procedūrų reikšmingai pagerejjo TRACE ir TAPS skalių rezultatai. Po 1 procedūros reikšmingai sumažejo nugaros statinè ištvermè, padidejjo pirštų-grindų atstumas (toliau - PGA), pagerèjo liemens disbalanso bei TRACE skalès rezultatai.
\end{abstract}

Išvados. Nors 10 Schroth procedūrų kursas yra ganetinai trumpas, po jo pagerejo daugelis parametrų (liemens raumenų ištvermè, stuburo paslankumas, išvaizdos vertinimas bei su stuburo iškrypimu susiję nugaros paviršiaus parametrai).

\section{Ivadas}

Skoliozè - stuburo nukrypimas nuo normalios vertikalios linijos, susidedantis iš šoninio stuburo išlinkimo ir slankstelių pasisukimo. Skoliozè gali būti keleto tipų, iš kurių kiekvienas turi specifines charakteristikas [1]. Paauglių idiopatinè skoliozè yra dažniausiai pasitaikanti skoliozès forma. Ji sudaro 80 proc. visų idiopatinès skoliozès atvejų, o jos dažnis populiacijoje svyruoja nuo 0,93 iki 12 procentu [2]. Tyrimų duomenys rodo, kad paauglių idiopatinè skoliozè diagnozuojama 6-8 proc. Lietuvos moksleivių [3]. Ši skoliozès forma greičiausiai progresuoja brendimo laikotarpiu ir gali sukelti psichologines problemas, skausmą, kvėpavimo sutrikimus ir funkcijų apribojimą $[4,5]$.

Daugybė genetinių ir aplinkos veiksnių daro įtaką paauglių idiopatinès skoliozès atsiradimui ir progresavimui, tačiau tikslios priežastys vis dar nežinomos ir jų nustatymas yra viena iš tyrinejjamų sričių. Skoliozès gydymo metodika priklauso nuo stuburo iškrypimo kampo (Cobb kampo). Pagrindinis skoliozės gydymo tikslas yra sustabdyti jos progresavimą, kol šis nepasiekè $50^{\circ}$ kampo, kai būtina chirurginè intervencija. Jei Cobb kampas mažesnis nei $25^{\circ}$, pacientas yra stebimas ir jam gali būti paskirta specifinè kineziterapija, o jei šis kampas yra tarp $25^{\circ}-45^{\circ}$, kartu su specifine kineziterapija naudojami koreguojamieji ittvarai [4, 6]. Specifinè kineziterapija gydant skoliozę turètų aprèpti: trimatę laikysenos autokorekciją, koreguotos laikysenos stabilizavimą ir korekcinių padèčių mokymą kasdieniame paciento gyvenime [7].

Vienas iš plačiausiai nagrinejjamų specialiosios kinezite- 
rapijos metodu yra Schroth metodas, kurio tikslas - stiprinti silpnus ir atpalaiduoti ịsitempusius raumenis, kartu derinant kvėpavimą, išmokyti pacientą korekcinių padèčių bei taisyklingų korekcinių pratimų. Schroth sistemoje klasifikuojama bloku principu: dubens-pilvo, juosmeninès stuburo dalies, krūtininès dalies ir pečių juostos blokai. Šis metodas nekelia didelių nepatogumų pacientui ir leidžia jam gyventi visaverti gyvenimą. Tyrimų apie Schroth metodikos efektyvumą Lietuvoje nera daug, o tyrime naudojama DIERS Formetric 4D diagnostinè sistema yra vienas iš moderniausiu diagnostikos metodų, skirtų stuburo ir laikysenos analizei $[5,8,9]$.

Tyrimo tikslas - ivertinti Schroth metodikos efektyvumą pacientų raumenų ištvermès, judesių amplitudžių didinimui bei laikysenos korekcijai paauglių idiopatinès skoliozès atvejais.

\section{Tyrimo objektas ir metodika}

Tyrimas vyko nuo $2019 \mathrm{~m}$. vasario iki balandžio mènesio. Tyrimo vieta - Vaikų ligonine, VULSK filialas. Tiriamieji buvo nepilnamečiai, todèl jų tèvai ar artimieji turejjo duoti sutikimą dalyvauti tyrime. Prieš duodant sutikimą, visa informacija, susijusi su tyrimu, buvo pateikta žodine forma tiriamiesiems, jų tėvams ar artimiesiems. Tyrime dalyvavo 20 asmenų. Tiriamiesiems buvo taikoma 10 kineziterapijos procedūrų Schroth gydymo metodu. Procedūros buvo atliekamos 5 kartus per savaitę. Trukmè - 30 minučių. Siekiant ịvertinti tiriamųų sveikatos būklès pokyčius bei kineziterapijos efektyvumą, testavimas atliktas 3 kartus: prieš reabilitaciją ( 1 testavimas), po 1 procedūros ( 2 testavimas) bei po reabilitacijos (3 testavimas).

1 lentelè. Bendroji tiriamųų charakteristika

\begin{tabular}{|l|c|c|c|c|}
\hline Parametrai & Vidurkiai & SN & $\begin{array}{c}\text { Mažiausioji } \\
\text { reikšmė }\end{array}$ & $\begin{array}{c}\text { Didžiausioji } \\
\text { reikšmė }\end{array}$ \\
\hline $\begin{array}{l}\text { Tiriamujų } \\
\text { skaičius }\end{array}$ & 20 & - & - & - \\
\hline Amžius & 15 & 2,26 & 11 & 17 \\
\hline Ūgis $(\mathrm{cm})$ & 166 & 12,68 & 136 & 182 \\
\hline Svoris $(\mathrm{kg})$ & 59 & 13,49 & 34 & 85 \\
\hline Lytis & $\begin{array}{c}\mathrm{m}=14, \\
\mathrm{v}=6\end{array}$ & - & - & - \\
\hline
\end{tabular}

Tiriamujų įtraukimo į tyrimą kriterijai: amžiaus grupè nuo 11 iki $18 \mathrm{~m}$., idiopatinès skoliozès diagnozè, stuburo iškrypimo kampas iki $45^{\circ}$ pagal Cobb.

Tiriamujų neịtraukimo ị tyrimą kriterijai: neidiopatinè skoliozè, praeityje chirurginè stuburo intervencija, gretutinès ūminès ligos, ūmūs skausmai, degeneracinès stuburo ligos, širdies ir kraujagyslių sistemos ligos, onkologinès ligos, osteoporozé, protinè negalia, nutukimas (KMI >29).

Tyrime atlikta: liemens raumenų (pilvo, nugaros ir šoninių) statinès ištvermès vertinimas pagal McGill; stuburo paslankumo vertinimas (lenkimasis ị priekị, tiesimasis, šoninis lenkimasis); liemens disbalanso vertinimas; dubens pakrypimo vertinimas; kifozinio ir lordozinio kampų matavimas; paviršiaus rotacijos laipsnio vertinimas; lateralinès deviacijos matavimas.

Taikyta DIERS Formetric 4D sistema, naudojama judejjimo bei atramos aparato sutrikimų diagnostikai. Pacientui stovint sistema tyrimo metu projektuoja baltos šviesos juostas ant nugaros. Fiksuojami vaizdiniai, identifikuojami atskaitos taškai, užfiksuojama tiksli paviršiaus asimetrija bei nustatomi tam tikri kauliniai žymenys. Gauti duomenys palyginami ir apskaičiuojami, atkuriamas trijų dimensijų paciento nugaros vaizdas. Šiuo diagnostiniu instrumentiniu tyrimo metodu atliekamas stuburo parametrų vertinimas frontalioje, sagitalineje ir horizontalioje plokštumose. Frontalioje plokštumoje analizuoti parametrai - dubens pakrypimas $\left(\mathrm{mm} /{ }^{\circ}\right)$ ir lateralinė deviacija $(\mathrm{mm})$. Dubens pakrypimas $(\mathrm{mm})$ išreiškia aukščio tarp kryžkaulių duobučių skirtumą. Lateralinè deviacija (mm) - tai stuburo šoninis nuokrypis nuo stuburo vidurio linijos ị dešinę arba ị kairę. Sagitalinejje plokštumoje analizuoti stuburo parametrai - liemens disbalansas $(\mathrm{mm})$, krūtinès kifozès $\left(^{\circ}\right)$ ir juosmens lordozès $\left(^{\circ}\right)$ kampai. Liemens disbalansą $(\mathrm{mm})$ nusako atstumas tarp iš C7 stuburo slankstelio išvesto statmens ir tarp kryžkaulio duobučių esančios vidurio linijos. Liemens disbalansas neturètų viršyti 7,5 mm. Horizontalioje plokštumoje buvo ivertinama ir analizuojama nugaros paviršiaus rotacija $\left({ }^{\circ}\right)$. Paviršiaus rotaciją apibūdina slankstelio pasisukimo apie vertikaliają ašị laipsnis. Tai skoliozės slankstelių rotacijos indeksas.

Tyrime naudotos skoliozei specifinès išvaizdos vertinimo skalès TRACE ir TAPS. TRACE skalè vertina ke-

2 lentelè. Liemens raumenų statinès ištvermès rezultatai ir jų pokyčiai

\begin{tabular}{|c|c|c|c|c|c|c|c|c|c|c|c|c|}
\hline & \multicolumn{3}{|c|}{ Pilvo raumenų ištvermė (s) } & \multicolumn{3}{|c|}{$\begin{array}{l}\text { Nugaros raumenụ } \\
\text { ištvermè (s) }\end{array}$} & \multicolumn{3}{|c|}{$\begin{array}{l}\text { Kairio šono raumenų } \\
\text { ištvermè (s) }\end{array}$} & \multicolumn{3}{|c|}{$\begin{array}{c}\text { Dešinio šono raumenụ } \\
\text { ištvermė (s) }\end{array}$} \\
\hline & $\begin{array}{l}\text { Prieš } \\
\text { reab. }\end{array}$ & $\begin{array}{l}\text { Po } 1 \\
\text { proc. }\end{array}$ & Po reab. & $\begin{array}{l}\text { Prieš } \\
\text { reab. }\end{array}$ & $\begin{array}{l}\text { Po } 1 \\
\text { proc. }\end{array}$ & Po reab. & $\begin{array}{l}\text { Prieš } \\
\text { reab. }\end{array}$ & $\begin{array}{l}\text { Po } 1 \\
\text { proc. }\end{array}$ & Po reab. & $\begin{array}{l}\text { Prieš } \\
\text { reab. }\end{array}$ & $\begin{array}{l}\text { Po } 1 \\
\text { proc. }\end{array}$ & Po reab \\
\hline Vidurkis & 56,35 & 55,85 & 91,05 & 90,10 & 85,30 & 116,10 & 42,95 & 43,45 & 58,00 & 39,30 & 39,70 & 55,85 \\
\hline SN & 33,79 & 30,95 & 47,06 & 37,18 & 35,19 & 44,31 & 22,22 & 21,27 & 24,09 & 19,77 & 19,02 & 20,49 \\
\hline
\end{tabular}


turis segmentus: pečius, mentis, juosmenị ir vidurinę krūtininès dalị. Kiekvienai daliai priskiriamas skirtingas balų skaičius: pečiai - 0-3, juosmuo - 0-4, mentès $-0-2$ ir krūtininès dalies vidurys $0-2$. Didžiausia balų suma yra 12 , reiškianti didžiausią asimetriją. TAPS yra savo kūno vaizdo suvokimo skalè. Ji susideda iš trijų paveikslèliu rinkinių: vaizdas iš nugaros, vaizdas iš priekio pasilenkus i priekị ir stovint veidu i priekị. Paskutinis rinkinys suskirstytas i du pogrupius, atskirai mergaitems ir berniukams. Kiekviename rinkinyje yra po penkis paveikslèlius, kurių vertinimas yra nuo 5 (mažiausia deformacija) iki 1 (didžiausia deformacija). Tiriamasis pats išsirenka po vieną paveikslèlį iš rinkinių. Gauti balai sumuojami ir skaičiuojamas vidurkis.

Tyrimo metu gauti rezultatai buvo apdoroti ir atlikta statistinè duomenu analizè. Statistinei duomenų analizei buvo naudojamos $\mathrm{R}$ ir Microsoft Excel programos. Duomenų pasiskirstymo pagal normalujji skirstini tikrinimui buvo naudojamas ShapiroWilk testas. Hipotezių apie populiacijų vidurkių lygybę tikrinimui buvo taikomi parametriniai testai $(\mathrm{t}$ - testas normalumą atitinkantiems

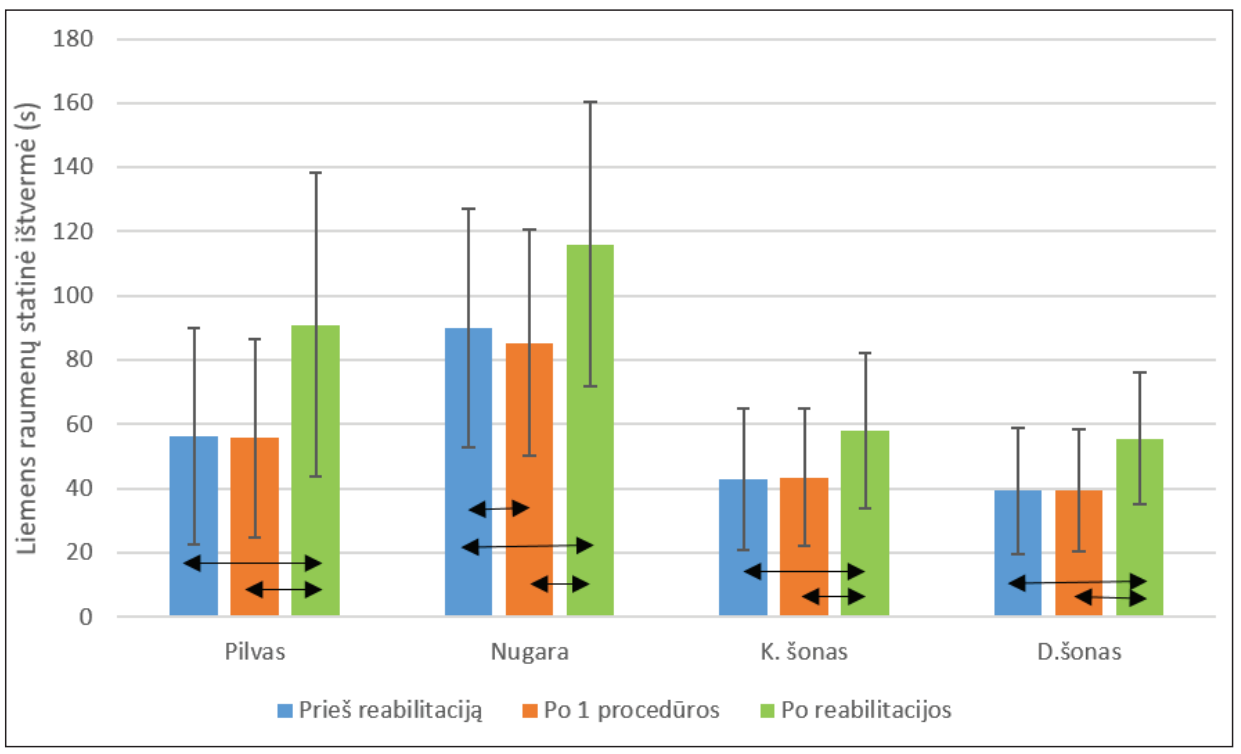

1 pav. Liemens raumenų statinės ištvermès rezultatai po 3 testavimų $(\leftrightarrow p<0.05)$

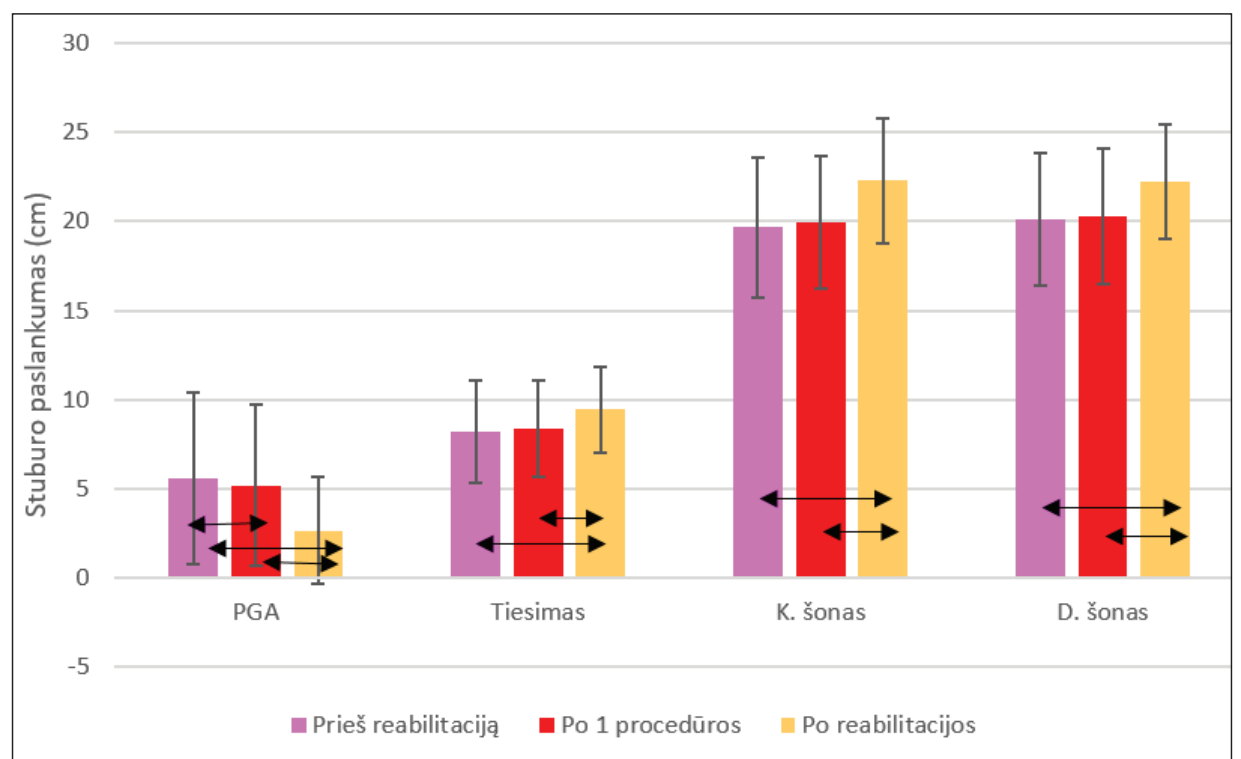

2 pav. Stuburo paslankumo rezultatai po 3 testavimų $(\leftrightarrow \mathrm{p}<0.05)$

3 lentelè. Stuburo paslankumo rezultatai ir jų pokyčiai

\begin{tabular}{|c|c|c|c|c|c|c|c|c|c|c|c|c|}
\hline & \multicolumn{3}{|c|}{$\begin{array}{l}\text { Pirštų-grindụ atstumas } \\
(\mathrm{cm})\end{array}$} & \multicolumn{3}{|c|}{$\begin{array}{l}\text { Liemens tiesimas } \\
(\mathrm{cm})\end{array}$} & \multicolumn{3}{|c|}{$\begin{array}{c}\text { Liemens lenkimas i } \\
\text { kairę }(\mathrm{cm})\end{array}$} & \multicolumn{3}{|c|}{$\begin{array}{l}\text { Liemens lenkimas ị } \\
\text { dešinę }(\mathrm{cm})\end{array}$} \\
\hline & $\begin{array}{l}\text { Prieš } \\
\text { reab. }\end{array}$ & $\begin{array}{l}\text { Po } 1 \\
\text { proc. }\end{array}$ & Po reab. & & $\begin{array}{l}\text { Po } 1 \\
\text { proc. }\end{array}$ & Po reab. & $\begin{array}{l}\text { Prieš } \\
\text { reab. }\end{array}$ & $\begin{array}{l}\text { Po } 1 \\
\text { proc. }\end{array}$ & $\begin{array}{l}\text { Po } \\
\text { reab. }\end{array}$ & & $\begin{array}{l}\text { Po } 1 \\
\text { proc. }\end{array}$ & $\begin{array}{l}\text { Po } \\
\text { reab. }\end{array}$ \\
\hline Vic & 5,6 & 5, & & 8,20 & & & 19,65 & 19,95 & 22,50 & 20,10 & 20,30 & 22,20 \\
\hline SN & 4,84 & 4,53 & 2,96 & 2,88 & 2,74 & 2,39 & 3,90 & 3,75 & 3,53 & 3,71 & 3,80 & 3,22 \\
\hline
\end{tabular}


duomenims), o neparametriniai testai buvo naudojami medianų lyginimui, t.y. Wilcoxon kriterijus duomenims, kurie netenkino normalumo sąlygos. Bet koks skirtumas buvo laikomas reikšmingu, jeigu $\mathrm{p}<0,05$.

\section{Tyrimo rezultatai}

Pirmoje lentelèje pateikta bendroji tiriamujjų charakteristika, požymių vidurkiai ir standartinis nuokrypis (SN). Tiriamujų imtị sudare 20 asmenų, iš kurių 14 buvo mergaitès, 6 - berniukai. Tiriamujų amžius svyravo nuo 11 iki 17 metu, vidurkis - 15 $\pm 2,26$ metų. Tiriamųų ūgis svyravo nuo 136 iki $182 \mathrm{~cm}$, vidurkis $166 \pm 12,68 \mathrm{~cm}$. Svoris svyravo nuo 34 iki $85 \mathrm{~kg}$, vidurkis $-59 \pm 13,49 \mathrm{~kg}$.

Pilvo, nugaros, kairiojo ir dešiniojo šonų liemens raumenų ištvermès vertinimo vidurkiai bei standartiniai nuo-

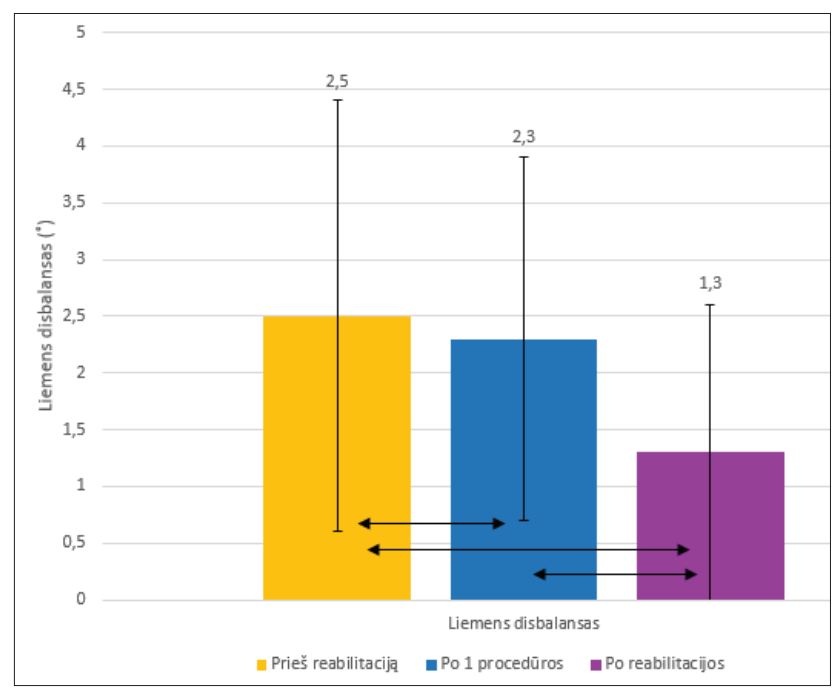

3 pav. Liemens disbalanso rezultatai $\left({ }^{\circ}\right)$ po 3 testavimų $(\leftrightarrow p<0.05)$

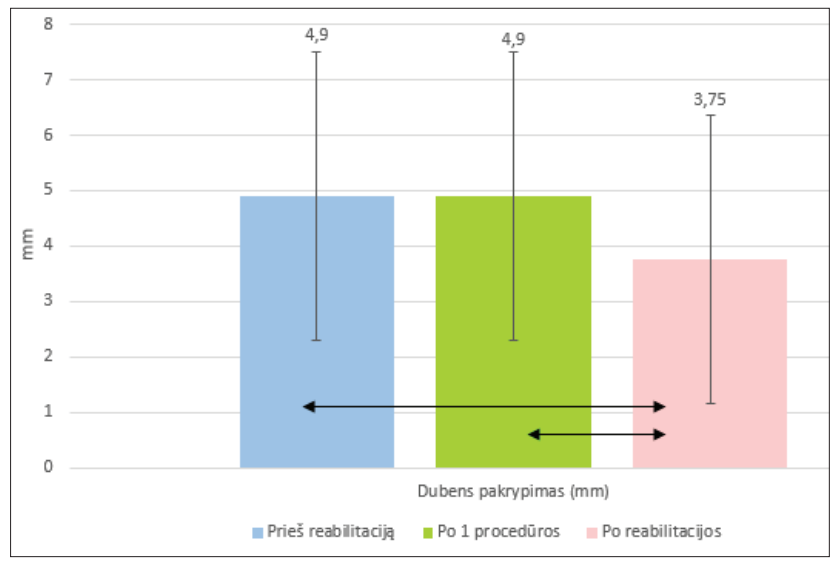

4 pav. Dubens pakrypimo rezultatai (mm) po 3 testavimu ( $\leftrightarrow$ $\mathrm{p}<0.05$ ) krypiai prieš reabilitaciją, po 1 procedūros ir po reabilitacijos pateikti 2 lenteleje. Pateikti duomenys vaizduoja vertinimo pokyčius, atlikus visus 3 testavimus. Palyginus gautus duomenis matyti, kad pilvo, kairiojo ir dešiniojo šonų rezultatai po 1 procedūros beveik nepakito (pilvo ištvermè sumažèjo $0,5 \mathrm{~s}$, kairiojo šono ištvermè padidejjo $0,5 \mathrm{~s}$, dešiniojo šono ištvermė padidèjo $0,4 \mathrm{~s}$ ), o nugaros ištvermè sumažèjo $4,8 \mathrm{~s}$. Palyginus rezultatus prieš ir po reabilitacijos galima matyti, kad visų parametrų rezultatai pagerèjo (pilvo ištvermè padidejo $34,7 \mathrm{~s}$, nugaros - $26 \mathrm{~s}$, kairiojo šono 15,05 s, o dešiniojo šono ištvermè padidèjo $16,55 \mathrm{~s}$ ).

Liemens raumenu statinès ištvermès testavimo rezultatu vidutiniai pokyčiai pateikiami 1 paveiksle. Rezultatai rodo, kad statistiškai reikšmingas skirtumas gautas tarp pirmo ir trečio testavimo rezultatų: pilvo ištvermès $(p<0,001)$, nugaros ištvermès $(p<0,001)$, kairiojo šono ištvermès $(p=0,048)$ bei dešiniojo šono ištvermès rezultatų $(\mathrm{p}=0,002)$; statistiškai reikšmingas skirtumas gautas tarp antro ir trečio testavimo rezultatų: pilvo ištvermès $(\mathrm{p}<0,001)$, nugaros ištvermès $(p<0,001)$, kairiojo šono ištvermès $(p<0,001)$ bei dešiniojo šno ištvermès rezultatų $(\mathrm{p}=0,002)$. Statistiškai reikšmingas skirtumas nustatytas tarp nugaros raumenų ištvermès rezultatų prieš reabilitaciją ir po 1 procedūros $(\mathrm{p}=0,003)$.

Tyrimo metu buvo vertinami stuburo paslankumo rodikliai - liemens lenkimas, tiesimas bei lenkimas ị kairę ir ị dešinę. Liemens lenkimas ị priekị buvo vertinimas matuojant PGA. Liemens lenkimo, tiesimo, kairiojo ir dešiniojo šonų liemens lenkimo vertinimo vidurkiai bei standartiniai nuokrypiai prieš reabilitaciją, po 1 procedūros ir po reabilitacijos pateikiami 3 lenteleje, kurios duomenys vaizduoja vertinimo pokyčius, atlikus visus 3 testavimus. Palyginus gautus duomenis galima matyti, kad visi keturi rodikliai pagerèjo po vienos procedūros (PGA padidejo $0,4 \mathrm{~cm}$, liemens tiesimas

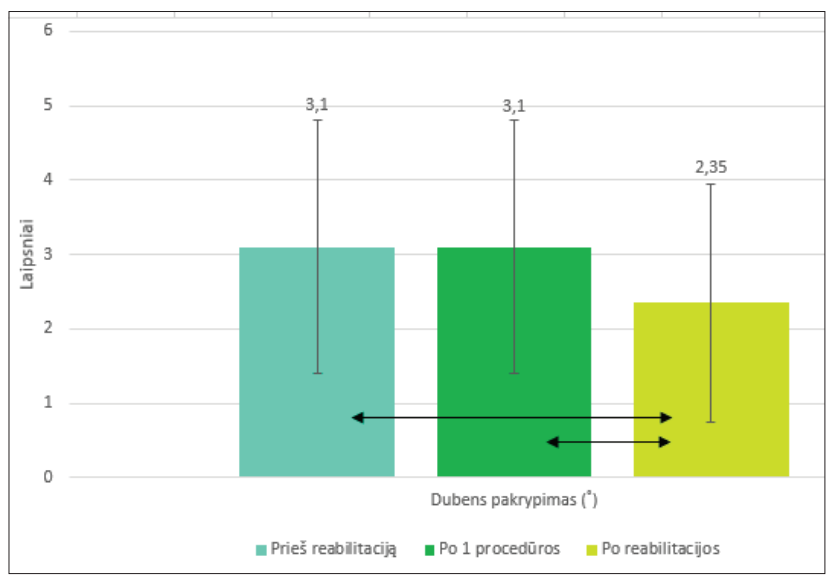

5 pav. Dubens pakrypimo rezultatai (laipsniais) po 3 testavimų $(\leftrightarrow \mathrm{p}<0.05)$ 
padidèjo $1,1 \mathrm{~cm}$, kairiojo šono paslankumas padidèjo $0,3 \mathrm{~cm}$, o dešiniojo $-0,2 \mathrm{~cm})$. Po reabilitacijos pagerejjimas buvo dar didesnis visose keturiose kategorijose (PGA padidejo $2,95 \mathrm{~cm}$, liemens tiesimas padidejo 1,25 $\mathrm{cm}$, kairiojo šono paslankumas padidejjo $2,85 \mathrm{~cm}$, o dešiniojo - 2,1 cm).

Stuburo paslankumo testavimo rezultatų vidutiniai pokyčiai pateikiami 2 paveiksle. Diagramoje galima matyti, kad nustatytas visų parametrų statistiškai reikšmingas skirtumas prieš reabilitaciją ir po jos: $\operatorname{PGA}(p=0,001)$, tiesimo $(p<0,001)$, kairiojo šono $(p<0,001)$, dešiniojo šono $(p<0,001)$ rezultatų, bei po 1 procedūros ir po reabilitacijos: PGA ( $p=0,001)$, tiesimo $(\mathrm{p}<0,001)$, kairiojo šono $(\mathrm{p}<0,001)$, dešiniojo šono $(\mathrm{p}<0,001)$ rezultatų. Statistiškai reišmingas skirtumas tarp pirmo ir antro testavimų nustatytas tik vienam parametrui - PGA $(\mathrm{p}=0,031)$. Kitų rodiklių statistiškai reikšmingo skirtumo tarp pirmų dviejų testavimų nenustatyta $(\mathrm{p}>0,05)$.

Liemens disbalanso testavimo rezultatų vidutiniai pokyčiai pateikiami 3 paveiksle. Po 1 procedūros liemens disbalansas sumažèjo vidutiniškai 0,2 laipsnio, o po reabilitacijos vidutiniškai 1,2 laipsnio. Rezultatai parode statis- tiškai reikšmingą skirtumą tarp pirmo ir antro $(\mathrm{p}=0,042)$, antro ir trečio $(\mathrm{p}=0,001)$, pirmo ir trečio $(\mathrm{p}<0,001)$ testavimo vidurkių.

Dubens pakrypimo milimetrais testavimo rezultatų vidutiniai pokyčiai pateikiami 4 paveiksle. Dubens pakrypimas po 1 procedūros buvo toks pat, kaip ir prieš reabilitaciją, o po reabilitacijos sumažějo vidutiniškai $1,15 \mathrm{~mm}$. Gautieji duomenys rodo, kad statistiškai reikšmingas skirtumas nustatytas tarp antro ir trečio $(p=0,013)$ bei pirmo ir trečio $(p=0,013)$ testavimo. Tarp pirmo ir antro testavimo statistiškai reikšmingo skirtumo nerasta.

Dubens pakrypimo laipsniais testavimo rezultatų vidutiniai pokyčiai pateikiami 5 paveiksle. Dubens pakrypimas po 1 procedūros buvo toks pat, kaip ir prieš reabilitaciją, o po reabilitacijos

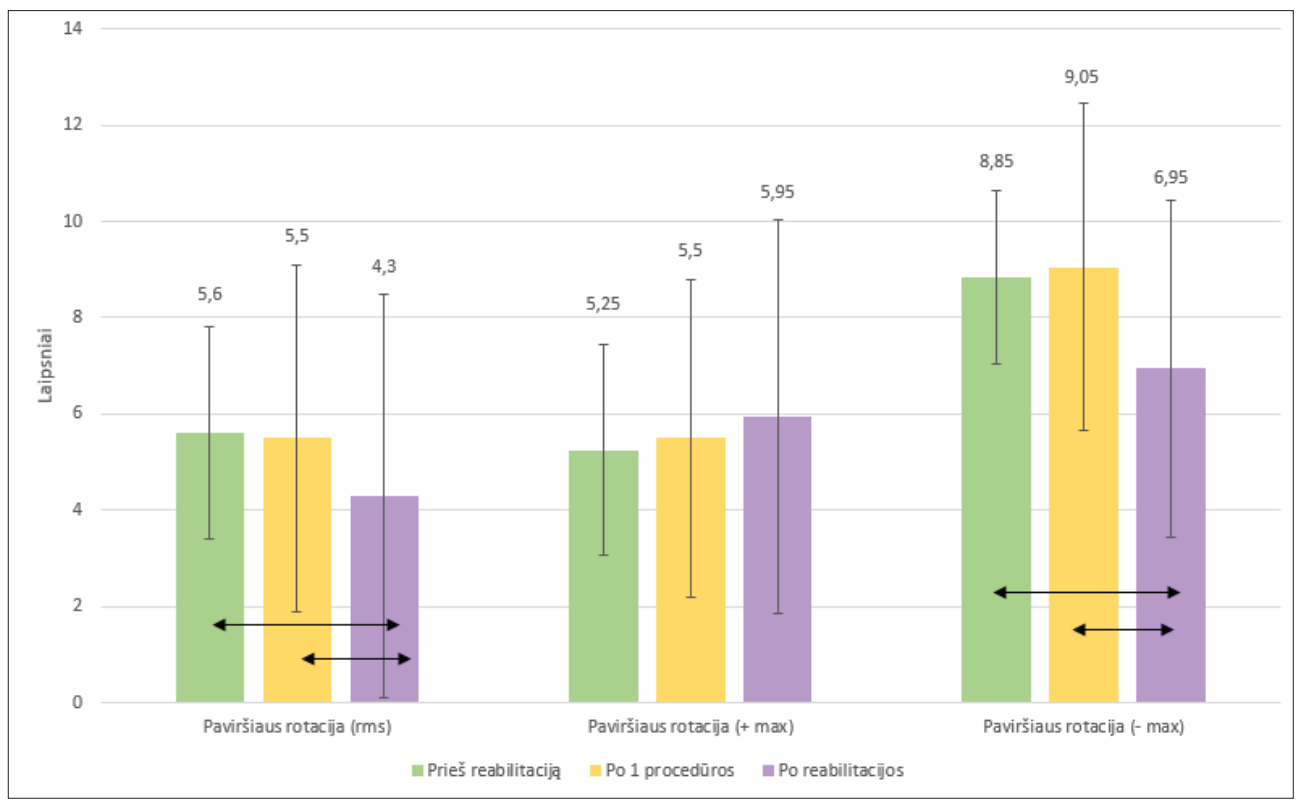

6 pav. Paviršiaus rotacijos rezultatai $\left(\mathrm{rms},+\max ,-\max \left({ }^{\circ}\right)\right)$ po 3 testavimų $(\leftrightarrow \mathrm{p}<0.05)$

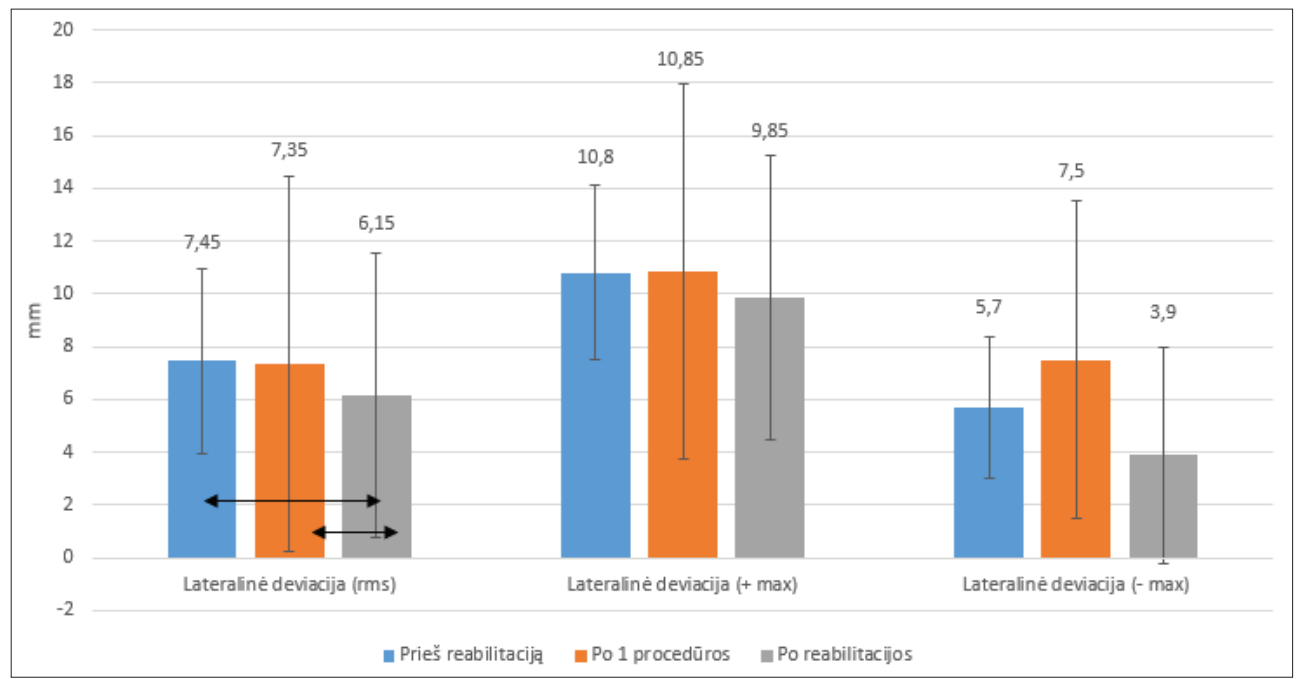

7 pav. Lateralinės deviacijos rezultatai $(\mathrm{rms},+\max ,-\max (\mathrm{mm}))$ po 3 testavimų $(\leftrightarrow \mathrm{p}<0.05)$ 
sumažèjo vidutiniškai 0,75 laipsnio. Gautieji duomenys rodo statistiškai reikšmingą skirtumą tarp antro ir trečio $(p=0,016)$ bei pirmo ir trečio $(\mathrm{p}=0,016)$ testavimo. Tarp pirmo ir antro testavimo statistiškai reikšmingo skirtumo nustatyta.

Tyrimo metu buvo vertinami krūtinès kifozès ir juosmens lordozès kampai. Po vienos procedūros krūtinès kifozès kampas sumažejjo vidutiniškai 0,15 laipsnio, po reabilitacijos - vidutiniškai 0,2 laipsnio. Po vienos procedūros juosmens lordozès kampas padidejo vidutiniškai 0,45 laipsnio, po reabilitacijos - vidutiniškai 0,85 laipsnio. Gauti skirtumai nebuvo statistiškai reikšmingi.

Nugaros paviršiaus rotacijos laipsnio (rms, + $\max ,-\max )$ vidutiniai pokyčiai prieš reabilitaciją, po 1 vienos procedūros ir po reabilitacijos pavaizduoti 6 paveiksle. Išanalizavus gautus duomenis matyti, kad paviršiaus rotacija (rms) po 1 procedūros vidutiniškai sumažèjo $0,1 \mathrm{~mm}$, o po reabilitacijos sumažejo vidutiniškai $1,3 \mathrm{~mm}$. Paviršiaus rotacija (+max) po 1 procedūros padidejjo 0,15 laipsnio, o po reabilitacijos buvo 0,7 laipsnio didesnè, nei prieš reabilitaciją. Tuo tarpu paviršiaus rotacija (-max) po 1 procedūros padidèjo 0,2 laipsnio, o po reabilitacijos sumažèjo 1,9 laipsnio, palyginus su duomenimis prieš reabilitaciją. Gautieji duomenys rodo, kad statistiškai reikšmingas skirtumas nustatytas paviršiaus rotacijos (rms) duomenims tarp antro ir trečio $(\mathrm{p}<0,001)$ bei pirmo ir trečio $(p<0,001)$ testavimo bei paviršiaus rotacijos $(-\max )$ duomenims tarp antro ir trečio $(\mathrm{p}=0,004)$ bei pirmo ir trečio $(\mathrm{p}=0,003)$ testavimo. Tarp kitų duomenų statistiškai reikšmingo skirtumo nenustatyta.

Lateralinès deviacijos milimetrais (rms, + max, -max) vidutiniai pokyčiai prieš reabilitaciją, po 1 vienos procedūros ir po reabilitacijos pavaizduoti 7 paveiksle. Lateralinė deviacija (rms) po 1 procedūros vidutiniškai sumažèjo $0,1 \mathrm{~mm}$, o po reabilitacijos sumažejo vidutiniškai $1,3 \mathrm{~mm}$. Lateralinè deviacija $(+\max )$ po 1 procedūros padidejo $0,05 \mathrm{~mm}$, o po reabilitacijos buvo $0,95 \mathrm{~mm}$ didesnè, nei prieš reabilitaciją. Lateralinè deviacija (-max) po 1 procedūros padidèjo 1,8 $\mathrm{mm}$, o po reabilitacijos sumažèjo $1,8 \mathrm{~mm}$, palyginus su duomenimis prieš reabilitaciją. Gautieji duomenys rodo, kad statistiškai reikšmingas skirtumas nustatytas lateralinès deviacijos (rms) duomenims tarp antro ir trečio $(p=0,001)$ bei pirmo ir trečio $(\mathrm{p}=0,001)$ testavimo. Tarp kitų duomenu statistiškai reikšmingo skirtumo nenustatyta.

Išvaizdos vertinimo skalių testavimo rezultatų vidutiniai pokyčiai parodyti 8 paveiksle. Statistiškai reikšmingas skirtumas nustatytas TAPS išvaizdos skalès duomenims prieš reabilitaciją ir po reabilitacijos $(\mathrm{p}<0,001)$ bei po 1 procedūros ir po reabilitacijos $(p<0,001)$. Taip pat statistiškai reikšmingas skirtumas nutatytas TRACE skalès rezultatams prieš reabilitaciją, po 1 procedūros $(\mathrm{p}=0,011)$ prieš reabilitaciją ir po jos $(\mathrm{p}<0,001)$, bei po 1 procedūros ir po reabilitacijos $(\mathrm{p}<0,001)$.

\section{Rezultatų aptarimas}

Schroth gydymo metodas tarptautineje praktikoje laikomas vienu efektyviausių skoliozės gydymo metodų. Tai moksliškai pagrịstas iškrypusios stuburo kreivès stabilizavimo ir koregavimo metodas [8]. $1992 \mathrm{~m}$. buvo tirtas šio metodo efektyvumas, taikant 6 savaičių Schroth gydymą. Daugiau nei $5^{0}$ pagal Cobb kampą stuburo iškrypimas sumažèjo 44 proc. visų tirtų pacientų [10]. Skoliozès gydymui

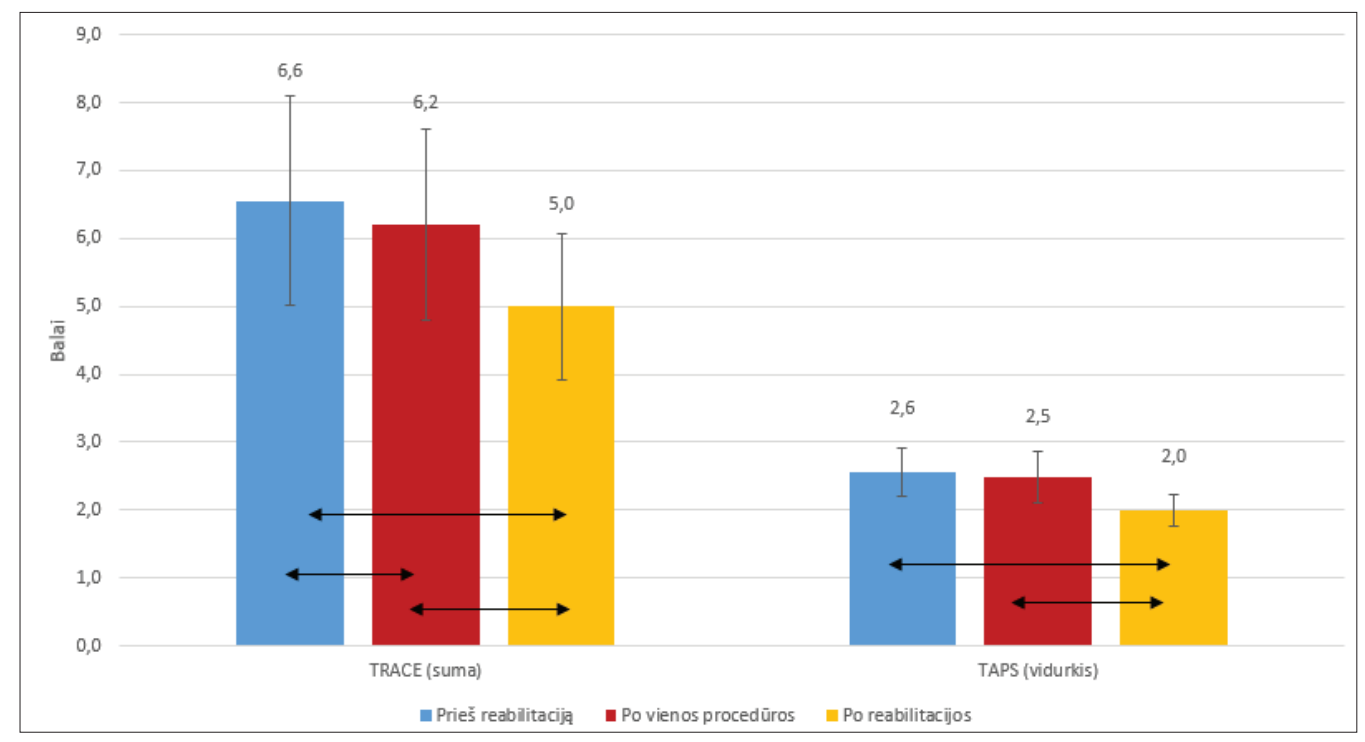

8 pav. Išvaizdos vertinimo skalių rezultatai po 3 testavimų $(\leftrightarrow p<0.05)$ 
taikant specialiają kineziterapiją, svarbu stiprinti paraspinalinius bei liemens raumenis, nes moksliniais tyrimais įrodyta, jog skoliozei būdingi degeneraciniai pakitimai ir išgaubtoje, ir igaubtoje stuburo puseje. S. Schreiber ir kt. 2015 m. atliktame tyrime buvo lyginami tiriamosios ir kontrolinès grupių liemens statinès ištvermès duomenys prieš ir po reabilitacijos. Nustatyta, kad tiriamosios grupès pacientų, kuriems buvo taikyta Schroth metodika, nugaros raumenų ištvermè padidèjo $32,3 \mathrm{~s}$, o kontrolinès grupès $-4,8 \mathrm{~s}$. Šis $27,5 \mathrm{~s}$ skirtumas buvo statistiškai reikšmingas [4]. Ne mažiau svarbu palaikyti stuburo judesių paslankumą, kadangi skoliozinè kreivè gali būti paslanki arba nepaslanki [11]. M. Hawes straipsnyje teigia, kad lankstumą didinantys ir jị palaikantys pratimai yra naudingi, nes idiopatinès skoliozès atvejais gali padèti išvengti chirurginio gydymo [12].

Šiame tyrime nustatyta, kad statinè liemens raumenų ištvermé statistiškai reikšmingai pagerèjo visose keturiose kategorijose (pilvo raumenų ištvermè pagerèjo $34 \mathrm{~s}$, nugaros raumenų - $26 \mathrm{~s}$, kairiojo šono raumenų - 15,05 s, o dešiniojo šono raumenų ištvermé pagerejjo 16,55 s). Visi skirtumai buvo statistiškai reikšmingi. Tiriant stuburo paslankumą nustatyta, kad po reabilitacijos pagerejjo stuburo lankstumas i visas keturias puses (PGA sumažèjo 2,95 cm, tiesimas padidejo $1,25 \mathrm{~cm}$, kairiojo šono paslankumas padidejo 2,85 $\mathrm{cm}$, o dešiniojo - 2,1 cm). Šie skirtumai yra statistiškai reikšmingi. Reikšmingas skirtumas prieš ir po reabilitacijos buvo nustatytas šiems nugaros parametrams: liemens disbalansui (sumažèjo 1,2 laipsnio), dubens pakrypimui mm bei laipsniais (sumažèjo 1,15 mm ir 0,75 laipsnio), paviršiaus rotacijai (sumažejo 1,3 $\mathrm{mm}$ ) bei lateralinei deviacijai (sumažèjo $1,3 \mathrm{~mm})$.

M. Rigo rekomenduoja idiopatine skolioze sergantiems vaikams ir paaugliams taikyti specialiają kineziterapiją, nes tai gali statistiškai reikšmingai sumažinti chirurginio gydymo poreiki [13]. T. Kuru ir kt. savo straipsnyje teigia, kad pacientus mokyti Schroth metodo reikia daug laiko ir gerai pasirengusio specialisto, kuris ne tik išmokytų pacientą tinkamai atlikti pratimus, bet ir gebėtu juos paskirti. Straipsnyje aprašytame tyrime buvo analizuojamas Schroth pratimų poveikis idiopatinès skoliozės atvejais. Pratimai buvo atliekami tris kartus per savaitę šešias savaites, o vienas užsiėmimas truko pusantros valandos. Tiriamieji buvo suskirstyti ị tris grupes: Schroth pratimai su specialisto priežiūra, Schroth pratimai savarankiškai namuose ir kontrolinę grupę, kuriai nebuvo taikomi jokie pratimai. Iš gautų rezultatų galima daryti išvadą, kad Schroth programa, daroma specialisto priežiūroje, yra statistiškai reikšmingai efektyvesnè, negu namų programa ar jokių pratimų netaikymas. Minèti autoriai nurodé, kad trečioje grupejje, kuriai kineziterapija nebuvo skirta, Cobb kampas padidejo [8].
Apibendrinant galima pasakyti, kad norint pasiekti efektyvių gydymo rezultatų, intensyvias Schroth procedūras reikètu taikyti bent dvi savaites. Siekiant ilgalaikių rezultatų, metodiką reiktų taikyti 6 ir daugiau savaičių. Lietuvoje reikètų populiarinti specialiają kineziterapiją, siekti, kad apie ją žinotų kuo daugiau žmonių ir skoliozės valdymui iš pradžių taikyti konservatyviojo gydymo metodus.

\section{Išvados}

1. Po vienos procedūros statistiškai reikšmingai sumažèjo nugaros raumenų statinè ištvermè, o po reabilitacijos statistiškai reikšmingai pagerejjo visi tiriamieji statinès liemens raumenų ištvermès parametrai.

2. Po vienos procedūros statistiškai reikšmingai pagerèjo PGA atstumas, o po reabilitacijos statistiškai reikšmingai pagerejo visi tiriamieji stuburo paslankumo parametrai.

3. Po vienos procedūros statistiškai reikšmingai pagerèjo liemens disbalanso bei TRACE skalès rezultatai. Po reabilitacijos statistiškai reikšmingai pagerejo liemens disbalanso, dubens pakrypimo, paviršiaus rotacijos, lateralinès deviacijos, TRACE bei TAPS skalių parametrai.

\section{Literatūra}

1. Lotan S, Kalichman L. Manual therapy treatment for adolescent idiopathic scoliosis. J Bodyw Mov Ther 2019;23(1):189-193. https://doi.org/10.1016/j.jbmt.2018.01.005

2. Negrini S, Donzelli S, Aulisa A, Czaprowski D, Schreiber S, De Mauroy JC, Diers H, et al. 2016 SOSORT guidelines: orthopaedic and rehabilitation treatment of idiopathic scoliosis during growth. Scoliosis Spinal Disord 2018;13:3.

https://doi.org/10.1186/s13013-017-0145-8

3. Adomaitienė I., Sinkevičius R., Stašienė E., Samuilis A., Raistenskis J., Strukčinskaitė V. Torakaliumbalinès fascijos pakitimų vertinimas ultragarso tyrimo pagalba esant paauglių idiopatinei skoliozei - bandomasis tyrimas. Sveikatos mokslai, 2016;26(2):72-77.

https://doi.org/10.5200/sm-hs.2016.030

4. Schreiber S, Parent E, Moez EK, Hedden DM, Hill D, et al. The effect of Schroth exercises added to the standard of care on the quality of life and muscle endurance in adolescents with idiopathic scoliosis - an assessor and statistician blinded randomized controlled trial: "SOSORT 2015 award winner". Scoliosis 2015;10:24.

https://doi.org/10.1186/s13013-015-0048-5

5. Schreiber S, Parent E, Khodayari ME, Hedden DM, et al. Schroth physiotherapeutic scoliosis-specific exercises added to the standard of care lead to better cobb angle outcomes in adolescents with idiopathic scoliosis - an assessor and statistician blinded randomized controlled trial. PLoS One 2016;11(12).

https://doi.org/10.1371/journal.pone.0168746

6. Ramirez J, Eberson C. The role of rehabilitation in the mana- 
gement of adolescent idiopathic scoliosis. Rhode Isl Med J 2017; 100(11): 22-25.

7. Kwan KYH, Cheng ACS, Koh HY, Chiu AYY, Cheung KMC. Effectiveness of Schroth exercises during bracing in adolescent idiopathic scoliosis: results from a preliminary study -SOSORT award 2017 winner. Scoliosis Spinal Disord 2017;12:32. https://doi.org/10.1186/s13013-017-0139-6

8. Kuru T, Yeldan İ, Dereli EE, Özdinçler AR, Dikici F, Çolak İK. The efficacy of three-dimensional Schroth exercises in adolescent idiopathic scoliosis: a randomized controlled clinical trial. Clinl Rehabil 2016; 30(2):181-190. https://doi.org/10.1177/0269215515575745

9. Weiss H. The method of Katharina Schroth - history, principles and current development. Scoliosis 2011;6:17. https://doi.org/10.1186/1748-7161-6-17

10. Dantas DS, De Assis SJ, Baroni MP, Lopes JM, Cacho EW, Cacho RO, Pereira SA. Klapp method effect on idiopathic scoliosis in adolescents: blind randomized controlled clinical trial. J Phys Ther Sci 2017;29(1):1-7. https://doi.org/10.1589/jpts.29.1

11. Wajchenberg M, Luciano RP, Martins DE, Rodrigues LMR, Puertas EB, Cohen M, et al. Hystological paraspinal muscle comparison between curve concavity and convexity in adolescent idiopathic scoliosis. Scoliosis 2014;9(1):O12. https://doi.org/10.1186/1748-7161-9-S1-O12

12. Hawes M. The use of exercises in the treatment of scoliosis: an evidence-based critical review of the literature. Ped Rehabil 2003;6(3-4):171-182. https://doi.org/10.1080/0963828032000159202

13. Rigo M, Reiter CH, Weiss HR. Effect of conservative management on the prevalence of surgery in patients with adolescent idiopathic scoliosis. Ped Rehabil 2003;6(3-4):209-214.

https://doi.org/10.1080/13638490310001642054

EFFECTIVENESS OF POSTURE CORRECTION USING SCHROTH PHYSIOTERAPY METHOD FOR PATIENTS WITH ADOLESCENT IDIOAPATHIC SCOLIOSIS

R. Sinkevičius, E. Sutkutė, J. Kairys, V. Radzevič, J. Raistenskis

Keywords: idiopathic scoliosis, Schroth method.
Summary

The aim of research work: Evaluate the effectiveness of Schroth's method for patients with adolescent idiopathic muscle endurance, range of motion, and scoliosis posture correction.

The study has been in progress since 2019. February to 2019 April. The place of the research is the Children's Hospital, the branch of the public institution VULSK. The study involved a total of 20 subjects. Subjects were given 10 physiotherapy procedures according to Schroth's method of treatment. In order to assess the changes in the health status of the subjects and the effectiveness of physiotherapy, the testing was carried out 3 times: before rehabilitation ( 1 test), after 1 procedure $(2$ test) and after rehabilitation (3 test).

To evaluate posture parameters the DIERS Formetric 4D system was used. For the evaluation of the endurance of torso muscles the McGill test was used, and the spine mobility was measured with a centimeter strip. TRACE (posture evaluation) and TAPS (self - perception) scales were also used.

Data analysis was performed using statistical analysis software $\mathrm{R}$ and MS Excel.

Results. After 10 procedures using the Schroth method, significantly improved the static endurance of the abdominal, back, left and right sides muscles, and the spinal mobility to all sides. Also, after 10 Schroth procedures, there was a significant improvement in torso imbalance, pelvic tilt, surface rotation, lateral deviation. After 10 procedures, the results of the TRACE and TAPS scales were significantly improved. After 1 procedure, significantly reduced back static endurance, increased PGA and improved torso imbalance and TRACE score.

Conclusions. Although the 10 Schroth procedures is quite short time it can improve many of the parameters (endurance of the torso muscles, spinal mobility, evaluation of the appearance and even the back surface parameters associated with spinal distortion).

Correspondence to: romualdas.sinkevicius@santa.lt

Gauta 2019-12-09 